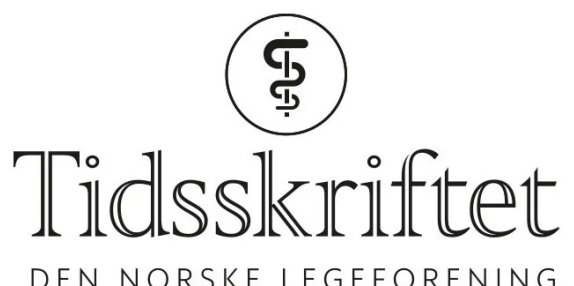

DEN NORSKE LEGEFORENING

\title{
Rettelse: Behandling, omsorg og pleie for døende sykehjemspasienter med covid-19
}

RETTELSE

SIREN ERIKSEN

ELLEN KARINE GROV

BJØRN LICHTWARCK

INGUNN HOLMEFOSS

KJELL BØHN

CHRISTIAN MYRSTAD

GEIR SELB AEK

BETTINA HUSEBØ

Tidsskr Nor Legeforen 2020; 140. doi: 10.4045/tidsskr.20.0306.

I Tabell 1 skal det stå: Perifer- og/eller sentraltvirkende analgetika før stell, ved behov, som fast ordinasjon.

Vi beklager feilen, den er rettet på nett.

Publisert: 29. april 2020. Tidsskr Nor Legeforen. DOI:10.4045/tidsskr.20.0374

(C) Tidsskrift for Den norske legeforening 2023. Lastet ned fra tidsskriftet.no 26. april 2023. 